\title{
Cholecystokinin A and B Receptors Are Differentially Expressed in Normal Pancreas and Pancreatic Adenocarcinoma
}

\author{
David S. Weinberg, ${ }^{\star}$ Bruce Ruggeri,, Michael T. Barber, ${ }^{\ddagger \S}$ Sanjoy Biswas, ${ }^{\ddagger \S}$ Sheila Miknyocki,, and Scott A. Waldman ${ }^{\ddagger \S}$ \\ $*$ Division of Gastroenterology and ${ }^{\ddagger}$ Division of Clinical Pharmacology, Department of Medicine, and ${ }^{\S}$ Department of Pharmacology, \\ Thomas Jefferson University, Philadelphia, Pennsylvania 19107; and $\|^{D}$ epartment of Pathology and Laboratory Medicine, Allegheny \\ University of the Health Sciences, Philadelphia, Pennsylvania 19102
}

\begin{abstract}
Cholecystokinin (CCK) plays an important role in pancreatic carcinogenesis. While human $\mathrm{CCK}-\mathrm{A}$ and $-\mathrm{B}$ receptors have been fully characterized, their relative roles in human pancreatic adenocarcinoma remain unclear. Thus, expression of CCK-A and -B receptors in normal human pancreas, pancreatic adenocarcinomas, and other human extrapancreatic tissues and malignancies was examined, using reverse transcription followed by the polymerase chain reaction (RT-PCR). mRNA isolated from 15 normal pancreas specimens, 22 pancreatic adenocarcinomas, and 58 extrapancreatic tissues and tumors was subjected to RT-PCR using primers specific for human CCK-A and -B receptors. Expression of CCK-B receptors was detected in all tissues arising from pancreas and in most extrapancreatic tissues and tumors. In contrast, $\mathrm{CCK}-\mathrm{A}$ receptors exhibited a more selective pattern of expression in gall bladder, intestine, brain, ovary, spleen, and thymus. Of significance, CCK-A receptors were expressed selectively in all pancreatic adenocarcinomas, but not in any normal pancreas specimens. In situ hybridization, using receptor-specific riboprobes, localized CCK-A receptor expression to ductal cells, the presumed origin of most human pancreatic adenocarcinomas. Southern blot analysis revealed no evidence of CCK-A receptor gene amplification or rearrangement in pancreatic adenocarcinomas. Because of its selective expression, the CCK-A receptor may serve as selective biomarker for pancreatic adenocarcinoma. (J. Clin. Invest. 1997. 100:597603.) Key words: pancreatic ductal cells • reverse transcription-polymerase chain reaction $\cdot$ in situ hybridization • DNA probe $\bullet$ tumor marker
\end{abstract}

\section{Introduction}

Pancreatic adenocarcinoma is the fifth leading cause of cancer death in the United States (1). The etiology of this malignancy is largely unknown. Advancing age, male gender, and smoking

Address correspondence to David Weinberg, M.D., Division of Gastroenterology, Department of Medicine, Thomas Jefferson University, 480 Main, Philadelphia, PA 19107. Phone: 215-955-7546; FAX: 215-923-3447; E-mail: weinber1@jeflin.tju.edu

Received for publication 27 February 1997 and accepted in revised form 2 May 1997.

J. Clin. Invest.

(c) The American Society for Clinical Investigation, Inc. 0021-9738/97/08/0597/07 \$2.00

Volume 100, Number 3, August 1997, 597-603

http://www.jci.org are established risk factors (2-5), while chronic pancreatitis (6) and diabetes (7) may be as well. The prognosis for patients with pancreatic cancer is poor, with reported 1-yr survival rates of $5-10 \%(8)$.

There is considerable evidence to support a central role for cholecystokinin $(\mathrm{CCK})^{1}$ in human pancreatic cancer (9). The influence of endogenous hormones is well-described for several human malignancies, including breast, ovary, and prostate. Generally, the hormones implicated are important in both the health and disease of their target organ. CCK is an important mediator in the growth of the normal pancreas $(10$, 11). Animal studies in which exogenous CCK was administered or in which endogenous CCK levels were manipulated documented pancreatic hyperplasia, dysplasia, and the production of frank malignancies (12). Similar studies after the induction of pancreatic tumors suggest that CCK administration accelerates the growth of malignant compared to uninvolved tissue $(13,14)$. In human cancer cell lines and xenografted human tumors, CCK promotes the growth of pancreatic adenocarcinoma $(15,16)$.

The identification of a specific molecular marker for pancreatic cancer could be of substantial diagnostic and therapeutic benefit. Two CCK receptors have been characterized and cloned in animal and human studies, CCK-A and -B (17). These receptors share structural homology and can be differentiated based on their binding affinities for CCK and another related gastrointestinal hormone, gastrin (18). The CCK-A receptor has an affinity for CCK which is 1,000-fold greater than that for gastrin, while the CCK-B receptor exhibits equivalent affinities for both peptides. Studies performed in rats demonstrated that in normal pancreas, the CCK-A receptor alone is expressed, while in pancreatic malignancies, the CCK-A receptor is over-expressed and the CCK-B receptor is newly expressed (19). In limited studies with human tissues, the CCK-B receptor has been identified on normal pancreas and pancreatic adenocarcinomas, although the latter is based predominantly on data obtained from immortalized cancer cell lines (20). There are no previous reports examining the expression of CCK-A receptors by human pancreatic adenocarcinomas.

The deficiencies of animal models for human pancreatic ductal adenocarcinomas are well-described $(21,22)$. Further, it is well-known that the behavior of human cancer cell lines in vitro does not necessarily parallel that of tissue in vivo. Therefore, the expression of CCK-A and -B receptors by human tissues harvested at surgery was examined to evaluate the utility of these receptors as biomarkers in normal and malignant human pancreas.

1. Abbreviations used in this paper: CCK, cholecystokinin; DIG, digoxigenin; RT, reverse transcription. 


\section{Methods}

\section{Clinical specimens}

Human tissues and blood were obtained under an Institutional Review Board-approved protocol from Thomas Jefferson University Hospital, the National Disease Research Interchange, and the Cooperative Human Tissue Network (Philadelphia, PA). More than 100 human tissue samples were examined for expression of CCK receptors, including 22 primary pancreatic tumors, 15 normal pancreatic specimens, 46 extrapancreatic tissue specimens, and 23 extrapancreatic tumors. Tissues were obtained from the operating room, and either processed immediately or frozen in liquid nitrogen and stored at $-70^{\circ} \mathrm{C}$ until use. Histopathologic diagnosis of pancreatic adenocarcinoma was confirmed in all cases.

\section{Nucleic acid extraction}

Total RNA was extracted from samples using a modified version of the acid guanidinium thiocyanate/phenol/chloroform method employing a single reagent (TRIzol reagent; GIBCO BRL, Gaithersburg, MD) $(23,24)$. Only samples exhibiting intact 28 s and 18 s ribosomal RNA were analyzed. mRNA was purified by Oligotex poly(A) ${ }^{+}$ mRNA affinity latex beads (QIAGEN Inc., Chatsworth, CA) using the manufacturer's protocol. Greater than $90 \%$ of the mRNA was recovered from total RNA in purified preparations. RNA preparations were stored in diethyl pyrocarbonate-treated water (RNase-free) at $-80^{\circ} \mathrm{C}$. To remove contaminating genomic DNA, the RNA was treated with $1 \mathrm{U} / \mu \mathrm{l}$ of RQ1 RNase-free DNase (Promega, Madison, WI) for $15 \mathrm{~min}$ at $37^{\circ} \mathrm{C}$, followed by a $30-\mathrm{min}$ incubation at $95^{\circ} \mathrm{C}$ with $1 \mu \mathrm{l}$ RNase inhibitor (PanVera Corp., Madison, WI).

\section{Reverse transcription-PCR (RT-PCR)}

RT of mRNA $(\leq 1 \mu \mathrm{g})$ purified from tissues was performed with 0.25 $\mathrm{U} / \mu \mathrm{l}$ of AMV reverse transcriptase XL (PanVera Corp.) containing $10 \mathrm{mM}$ Tris- $\mathrm{HCl}$ ( $\mathrm{pH} 8.3$ ), $50 \mathrm{mM} \mathrm{KCl}, 4 \mathrm{mM} \mathrm{MgCl} 2,1 \mathrm{mM}$ each dATP, dCTP, dGTP, and dTTP, $1 \mathrm{U} / \mu \mathrm{l}$ RNase inhibitor, and $1 \mu \mathrm{M}$ of CCK-A or CCK-B receptor-specific antisense primer (nucleotides $817-835$ or $506-526$, respectively) in a total volume of $20 \mu \mathrm{l}(25)$. Thermal cycling proceeded for 1 cycle at $55^{\circ} \mathrm{C}$ for $30 \mathrm{~min}, 99^{\circ} \mathrm{C}$ for 5 min (to inactivate the reverse transcriptase), and $4^{\circ} \mathrm{C}$ for $5 \mathrm{~min}$. The resultant cDNA was subjected to PCR in the same reaction tube, and included $2.5 \mathrm{U}$ of TaKaRa Taq polymerase (PanVera Corp.) in $100 \mu \mathrm{l}$ of $10 \mathrm{mM}$ Tris- $\mathrm{HCl}, 50 \mathrm{mM} \mathrm{KCl}, 2.5 \mathrm{mM} \mathrm{MgCl}$, and $0.2 \mu \mathrm{M}$ of a CCK-A or CCK-B receptor-specific sense primer (nucleotides 583601 or $247-266$, respectively) $(25,26)$. Incubation and thermal cycling conditions were $95^{\circ} \mathrm{C}$ for $2 \mathrm{~min}, 1 \mathrm{cycle} ; 94^{\circ} \mathrm{C}$ for $30 \mathrm{~s}, 58^{\circ} \mathrm{C}$ for $30 \mathrm{~s}$, $72^{\circ} \mathrm{C}$ for $90 \mathrm{~s}, 35$ cycles; $72^{\circ} \mathrm{C}$ for $7 \mathrm{~min}, 1$ cycle. Some tissues were analyzed as described above, using sequential CCK receptor-specific PCR. In these studies, first-round amplification reactions (35 cycles) used antisense- and sense-specific primers as outlined above. Secondround amplification reactions ( 35 cycles) were initiated using $10 \mu \mathrm{l}$ of the amplified cDNA solution from first-round reactions in a final volume of $100 \mu \mathrm{l}$ under the same PCR conditions. Primers specific for human $\beta$-actin (CLONTECH, Palo Alto, CA) were used as a positive control for RT-PCR reactions (27).

\section{Southern blotting}

$10 \mu \mathrm{g}$ of genomic DNA from 15 separate histologically confirmed pancreatic adenocarcinoma specimens was digested with EcoR1 and Bgill and subjected to Southern blot analyses on $0.8 \%$ agarose gels using an alkaline $(0.4 \mathrm{~N} \mathrm{NaOH})$ transfer method (28). Nylon membranes (Gene Screen Plus; New England Nuclear, Waltham, MA) were hybridized with an 18-mer digoxigenin (DIG)-labeled oligonucleotide probe corresponding to a highly conserved region of the CCK-A receptor coding sequence. After high stringency washes, blots were visualized using an enhanced chemiluminescence protocol (Boehringer Mannheim Corp., Indianapolis, IN). Rehybridization with a $1.3 \mathrm{kbp}$ EcoR1 cDNA fragment of human $\beta$-actin was performed to normalize for DNA loading.

\section{In situ hybridization}

Probe synthesis and DIG labeling protocol. Riboprobes were synthesized (BioServe Biotechnologies, Laurel, MD) from sequences corresponding to bp 817-835 of the CCK-A receptor gene (antisense: CCA CCA UCA UCA CAA UUC C; sense: CCU UAA CAC UAC UAC CAC C), and from sequences corresponding to bp 506-526 of the CCK-B receptor gene (antisense: AUU CCC AGG AAU GAG AGA AAG; sense: GAA AGA GAG UAA GGA CCC UUA). An oligo d(T) probe (Novacastra Laboratories Ltd., Newcastle-uponTyne, UK) was used as a control to evaluate the quality of the RNA. A DIG Oligonucleotide 3'-End Labeling Kit (Boehringer Mannheim) was used to label the probes. Briefly, $5 \mathrm{nmol} / \mathrm{ml}$ of probe was incubated in a solution containing $1 \times$ reaction buffer, $5 \mathrm{mM} \mathrm{CaCl}$, 0.5/0.5 mM DIG dUTP/dNTP tailing mixture, $5 \mathrm{mM}$ dATP, $2.5 \mathrm{U} / \mu \mathrm{l}$ terminal transferase, and sterile water for $15 \mathrm{~min}$ at $37^{\circ} \mathrm{C}$. Glycogen and $200 \mathrm{mM}$ EDTA, pH 8.0, was then added to stop the reaction. The probe was precipitated overnight at $-70^{\circ} \mathrm{C}$ with $4 \mathrm{M} \mathrm{LiCl}$ and $100 \%$ ethanol, centrifuged at $4^{\circ} \mathrm{C}$ for $15 \mathrm{~min}(13,000 \mathrm{~g})$, and washed with $70 \%$ ethanol. The pellet was dried, resuspended in TE buffer (Tris- $\mathrm{HCl}$ EDTA) at $\mathrm{pH} 8.0$, and stored at $-70^{\circ} \mathrm{C}$ until needed. Probes were quantified using serial dilutions $0.25 \mathrm{pmol} / \mu \mathrm{l}-0.25 \mathrm{fmol} / \mu \mathrm{l}$. The dilutions were spotted onto a positively charged nylon membrane (Boehringer Mannheim) and cross-linked using a UV Stratalinker (model 1800; Stratagene, La Jolla, CA). Spots were detected by rinsing the membrane in maleate buffer (100 mM maleic acid, $150 \mathrm{mM} \mathrm{NaCl}, \mathrm{pH} 7.5)$, incubating for $10 \mathrm{~min}$ in $1 \times$ blocking solution (Boehringer Mannheim), washing in maleate buffer with $3.0 \%$ ( $\mathrm{vol} / \mathrm{vol})$ Tween 20 , equilibrating in detection buffer $(100 \mathrm{mM}$ Tris- $\mathrm{HCl}, 100 \mathrm{mM} \mathrm{NaCl}, \mathrm{pH} 9.5$, and $50 \mathrm{mM}$ $\mathrm{MgCl}_{2}$ ), and incubating for 1-2 $\mathrm{h}$ in the dark in freshly prepared NBT/X phosphate solution (Boehringer Mannheim). The yield of DIG-labeled probe was determined by comparison to a DIG-labeled control.

In situ hybridization. In situ hybridization using the DIG-labeled probes was performed as described previously $(29,30)$. All solutions were treated with diethyl pyrocarbonate and all glassware was baked at $240^{\circ} \mathrm{C}$ overnight to prevent RNA degradation. 5- $\mu \mathrm{m}$ paraffinembedded tissues were deparaffinized in xylene, rehydrated in an ethanol series $(100,100,95$, and $70 \%)$, and washed twice for $5 \mathrm{~min}$ in PBS. Tissue sections were incubated in $0.1 \mathrm{M}$ glycine for $5 \mathrm{~min}$ and $0.3 \%$ Triton X-100 for 15 min to reduce background. Slides were incubated for $30 \mathrm{~min}$ in proteinase $\mathrm{K}$ solution $(10 \mu \mathrm{g} / \mathrm{ml})$, postfixed for $5 \mathrm{~min}$ in $4 \%$ paraformaldehyde, and acetylated in $0.25 \%$ acetic anhydride for $10 \mathrm{~min}$. Tissue sections were incubated for $2 \mathrm{~h}$ in a humidified chamber at $37^{\circ} \mathrm{C}$ with prehybridization solution containing $50 \%$ deionized formamide, $4 \times$ SSC, $1 \times$ Denhart's solution, $500 \mu \mathrm{g} / \mathrm{ml} \mathrm{de}-$ natured salmon sperm, $250 \mu \mathrm{g} / \mathrm{ml}$ yeast tRNA, and $10 \%$ dextran sulfate. After prehybridization, slides were incubated overnight at $37^{\circ} \mathrm{C}$ in a humidified chamber with hybridization solution (prehybridization solution plus $100 \mathrm{pmol} / \mathrm{ml}$ probe). Posthybridization washes were $2 \times \mathrm{SSC}$ for $15 \mathrm{~min}$ at $42^{\circ} \mathrm{C}$ (twice), $1 \times \mathrm{SSC}$ for $15 \mathrm{~min}$ at $42^{\circ} \mathrm{C}$ (once), $0.5 \times \mathrm{SSC}$ for $15 \mathrm{~min}$ at $42^{\circ} \mathrm{C}$ (twice), and $1 \times$ maleate buffer for $1 \mathrm{~min}$ at room temperature. Signals were detected by incubating in $2 \times$ blocking solution (Boehringer Mannheim) at room temperature followed by incubation with anti-DIG alkaline phosphatase antibody (1:500; Boehringer Mannheim) in $2 \times$ blocking solution for $4 \mathrm{~h}$ at $37^{\circ} \mathrm{C}$. Slides were washed in maleate buffer and color detection buffer (Boehringer Mannheim) for $10 \mathrm{~min}$ each, then incubated in freshly prepared NBT/X phosphate (Boehringer Mannheim) color development solution overnight in a light-sealed humidified chamber. The reaction was stopped by washing slides in TE buffer, $\mathrm{pH}$ 8.0, and coverslipped with Biomeda (Fisher Scientific, Pittsburgh, PA).

\section{Results}

Expression of $C C K-A$ and $-B$ receptors by $R T-P C R$. Studies examining normal human pancreas and pancreatic adenocarcinomas have been inconclusive in defining the expression of CCK-A and -B receptors. Therefore, the specificity of expres- 


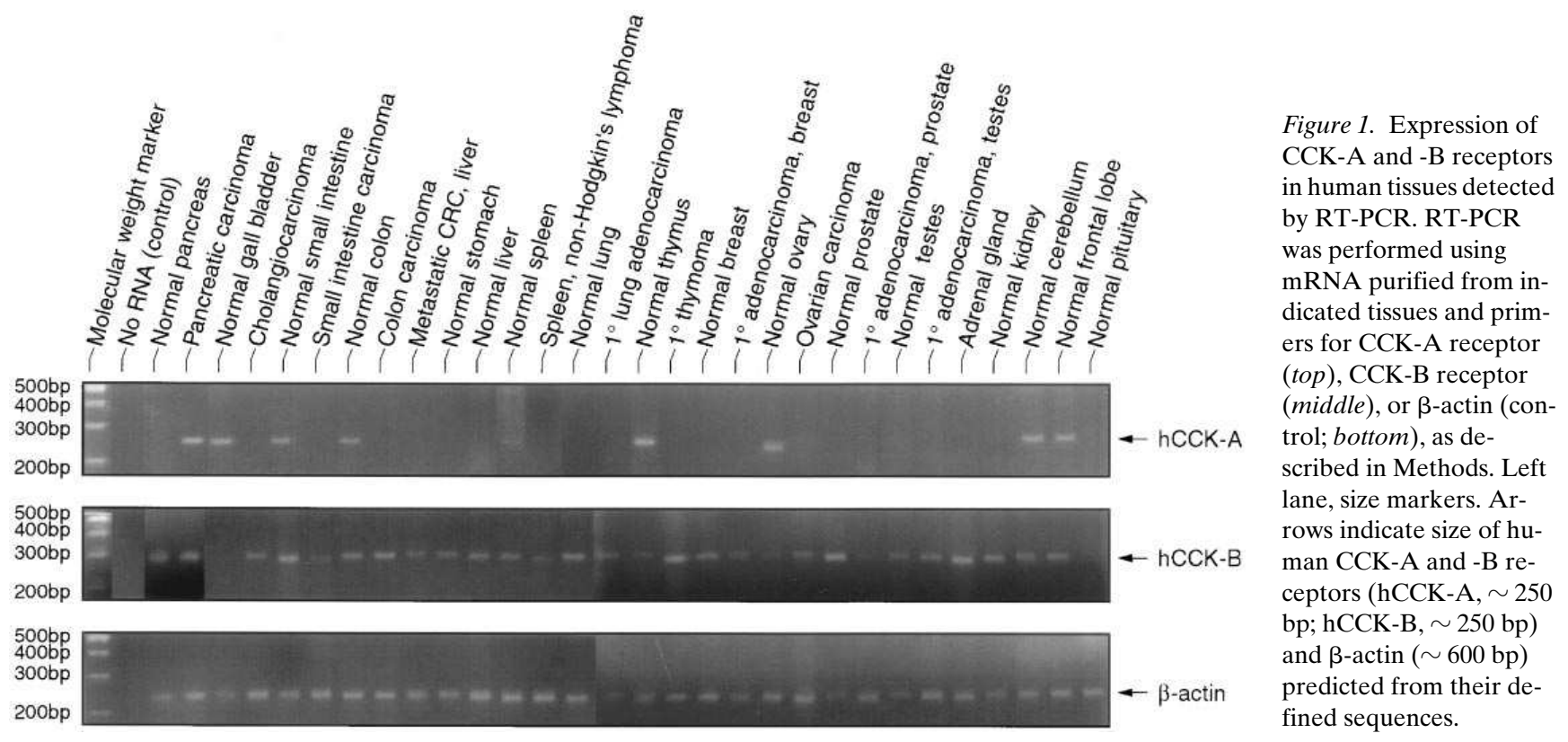

Table I. Tissues in which CCK-A and-B Receptors Were Detected by RT-PCR

\begin{tabular}{|c|c|}
\hline CCK-A & CCK-B \\
\hline Pancreatic adenocarcinoma (22)* & Pancreas (15) \\
\hline Gall bladder (2) & Pancreatic adenocarcinoma (22) \\
\hline Small intestine (2) & Small intestine (2) \\
\hline Colon (4) & Liver (4) \\
\hline Spleen (1) & Small intestine \\
\hline Ovary (2) & adenocarcinoma (1) \\
\hline Cerebellum (4) & Colon (4) \\
\hline \multirow[t]{23}{*}{ Frontal lobe (2) } & Colon carcinoma (6) \\
\hline & $\begin{array}{l}\text { Colon carcinoma metastatic to } \\
\text { liver (1) }\end{array}$ \\
\hline & Stomach (2) \\
\hline & Spleen (1) \\
\hline & Spleen, non-Hodgkin's \\
\hline & lymphoma (1) \\
\hline & Lung (3) \\
\hline & Lung adenocarcinoma (1) \\
\hline & $\begin{array}{l}\text { Lung squamous cell } \\
\text { carcinoma (1) }\end{array}$ \\
\hline & Thymus (1) \\
\hline & Thymoma (1) \\
\hline & Ovary (2) \\
\hline & Ovarian adenocarcinoma (1) \\
\hline & Breast (1) \\
\hline & Breast adenocarcinoma (1) \\
\hline & Prostate (2) \\
\hline & Prostate adenocarcinoma (4) \\
\hline & Testes (2) \\
\hline & Seminoma (3) \\
\hline & Kidney (3) \\
\hline & Adrenal (2) \\
\hline & Cerebellum (4) \\
\hline & Frontal lobe (2) \\
\hline
\end{tabular}

*Number of samples evaluated. sion of CCK-A and -B receptors for normal and malignant pancreas was examined to determine if the mRNA encoding these proteins could be detected by RT-PCR in normal human pancreas, pancreatic adenocarcinomas, and other extrapancreatic human tissues and tumors. CCK-A and -B receptor-specific primers used in these studies correspond to nonhomologous portions of the extracellular domains of each receptor. RT-PCR conducted with CCK-B receptor-specific primers and mRNA extracted from normal pancreas yielded an amplification product of $\sim 300$ bases, the size predicted from the defined sequence of that protein (31) (Fig. 1). This amplification product was identified in all specimens of normal pancreas and pancreatic adenocarcinoma examined (Table I). Sequencing of amplification products confirmed their identity as derived from CCK-B receptor mRNA. These data are in close agreement with those reported previously for normal pancreas and pancreatic tumors in humans $(18,32)$. In addition to the pancreas specimens, CCK-B receptor expression was detected in various extrapancreatic human tissues and tumors (Fig. 1; Table I).

RT-PCR of mRNA from normal human pancreas using CCK-A receptor-specific primers did not yield amplicons, suggesting that this receptor is not expressed in that tissue (Fig. 1, Table II). Amplification products could not be detected in any normal pancreatic samples examined despite two sequential rounds of PCR using CCK-A receptor-specific primers (Fig. 2 $A)$. The cystic fibrosis transmembrane conductance regulator, a marker for normal human pancreas, was detected in these specimens using this technique $(33,34)$ (Fig. $2 A$ ).

Of significance, RT-PCR using CCK-A receptor-specific primers and mRNA extracted from pancreatic adenocarcinomas resulted in an amplification product of $\sim 300$ bases, the size predicted from the defined sequence of that protein (35) (Fig. 1, Table I). This amplification product was identified in mRNA extracted from all samples of pancreatic adenocarcinomas examined (Table I). Sequencing of amplification products confirmed their identity as derived from CCK-A receptor mRNA (data not shown). These data are in contrast to those reported previously concerning the expression of CCK-A re- 
Table II. Tissues in which CCK-A and -B Receptors Were Not Detected by RT-PCR

\begin{tabular}{ll}
\hline \multicolumn{1}{c}{ CCK-A } & \multicolumn{1}{c}{ CCK-B } \\
\hline Pancreas (15)* & Gall bladder (2) \\
Situitary (1) \\
Colon carcinoma (6)
\end{tabular}

*Number of samples evaluated. ${ }^{\ddagger}$ CCK-B receptor expression was detected in mRNA isolated from gall bladder using two sequential rounds of PCR.

ceptors in pancreatic adenocarcinomas (20). Compared to the wide expression of CCK-B receptors in many extrapancreatic tissues and tumors, CCK-A receptor expression appears to be limited to select tissues, including gall bladder, intestine, ovary, spleen, and brain, as demonstrated previously $(32,33,36,37)$ (Table I). Prior studies have suggested that CCK-A receptors are expressed on human stomach and kidney (32). However, these receptors could not be detected in specimens of these tissues using RT followed by two sequential rounds of PCR (Fig. $2 A$ ). Of significance, CCK-A receptors appear to be selectively expressed by pancreatic adenocarcinomas but not by other extrapancreatic tumors originating within and outside the peritoneum (Fig. 1, Table I).

Localization of $C C K-A$ and $-B$ receptor expression in normal pancreas and pancreatic adenocarcinoma by in situ hybridization. Selective expression of CCK-A and -B receptors in normal pancreas and pancreatic adenocarcinoma was examined further, using in situ hybridization to identify the cells expressing these receptors. Probes specific for CCK-B receptors specifically hybridized with mRNA in sections of normal pancreas and pancreatic adenocarcinoma. Staining was specific for CCK-B receptors since sense probes to the identical sequence did not produce specific staining. In contrast, probes specific for CCK-A receptors did not produce specific staining in normal pancreas, in close agreement with results obtained by RTPCR. However, these probes produced specific staining of cells in sections of pancreatic adenocarcinoma, confirming the results obtained by RT-PCR (Fig. $2 B$ ). Hybridization with CCK-A receptor-specific probes occurred in ductal rather than acinar cells, consistent with the clinical observation that most human pancreatic adenocarcinomas are presumably of ductal origin (38).

Southern blot analysis. Southern blot analysis using an oligonucleotide probe specific for the CCK-A receptor sequence revealed the absence of CCK-A receptor gene amplification or rearrangement in pancreatic adenocarcinomas, compared to normal pancreas (Fig. 2 C).

\section{Discussion}

The data presented are the first to evaluate expression of CCK-A receptors by RT-PCR using RNA extracted from multiple normal and malignant human pancreatic tissue specimens. They demonstrate that the human CCK-A receptor is selectively expressed by pancreatic adenocarcinoma, but not by normal pancreas. Selective tissue expression was detected by RT-PCR and in situ hybridization. This receptor appears to be expressed only by a limited number of extrapancreatic tissues, but not by other intra- and extraabdominal tumors examined. Expression in pancreatic adenocarcinomas was localized to neoplastic pancreatic ductal cells by in situ hybridization. By comparison, CCK-B receptors were widely expressed by both normal and neoplastic pancreatic tissue, and by most other normal and neoplastic extrapancreatic tissues examined. The expression of CCK-A receptors by human pancreatic adenocarcinomas, but not by normal pancreas or other extrapancreatic tumors examined, suggests that this receptor may have utility as a relatively selective biomarker for the diagnosis and staging of pancreatic tumors $(39,40)$.

The relative expression of CCK-A and -B receptors in normal human pancreas has been examined previously (18). Studies using Northern blotting and ligand binding revealed CCK-B but not CCK-A receptors on normal human pancreas, implying that CCK-B alone is expressed in that tissue (17). The absence of CCK-A receptors and their transcripts in normal human pancreas is consistent with the observation that CCK-induced pancreatic exocrine secretion is mediated by neurogenic mechanisms involving vagal afferent pathways, rather than by directly affecting pancreatic acinar cell function (41).

A previous study examined the expression of CCK-A and -B receptors in normal human pancreas, using PCR primers with substantially overlapping homology to both receptors and commercially obtained cDNA libraries. Amplicons for CCK-B but not CCK-A receptors were detected by ethidium bromide staining (32). Interestingly, Southern blot analysis of the electrophoretically separated products revealed a band of the appropriate size for the CCK-A receptor. However, those results must be considered carefully since application of the same Southern blotting technique failed to detect CCK-B receptor expression in a normal human brain cDNA library in which a PCR amplicon was readily detected by ethidium bromide. In addition, CCK-A receptor expression was detected by this Southern blotting technique in normal human stomach and kidney (32). In this study, expression of this receptor could not be detected in those tissues despite the use of a PCR technique which can amplify the presence of rare transcripts up to $10^{20}$ fold.

Previous reports examining the type and distribution of CCK receptors in animal pancreas have yielded results which may not be directly applicable to humans. CCK-A receptors have been observed on both normal and neoplastic rat pancreas $(21,42)$. In some cases of rat pancreatic adenocarcinoma, 


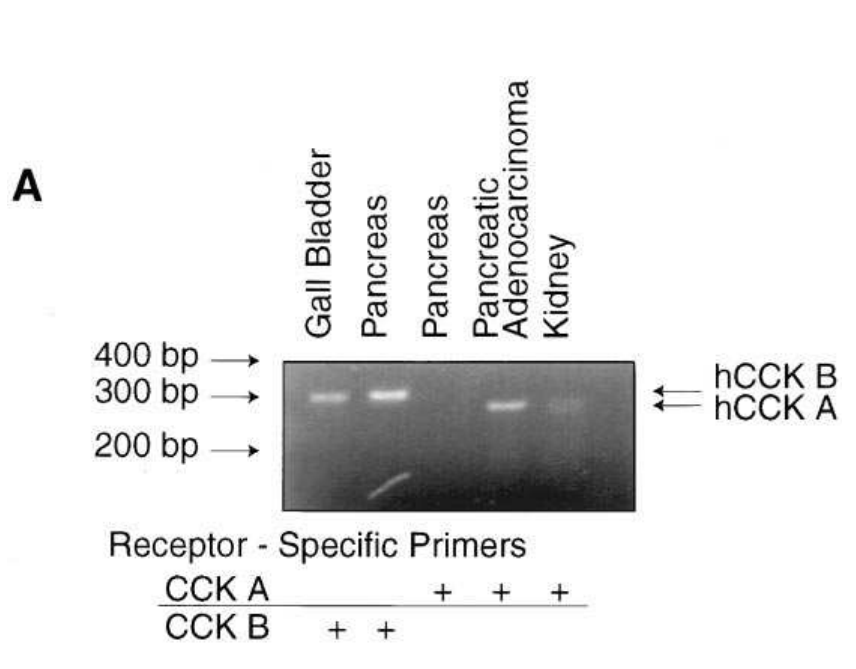

B

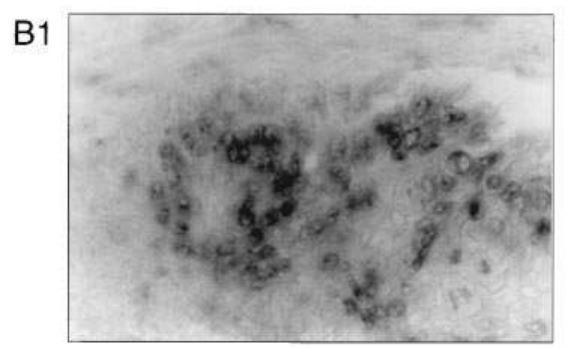

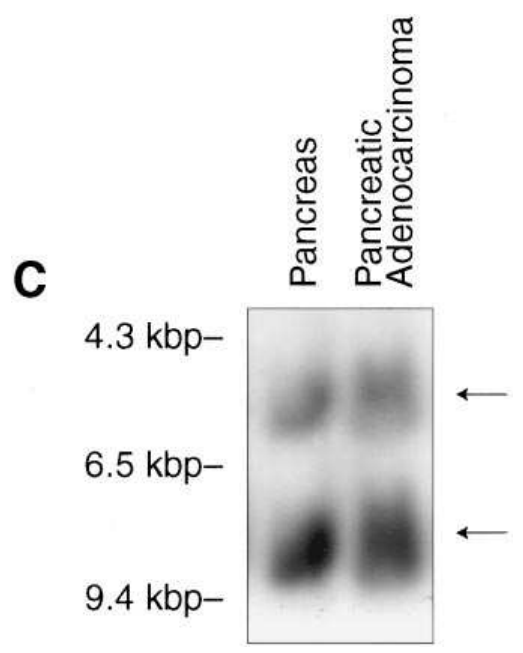

Figure 2. (A) Expression of CCK-A and -B receptors in select human tissues detected by RT-PCR. RT-PCR was performed using mRNA purified from indicated tissues and primers for human CCK-A receptor ( $h C C K A)$, human CCK-B receptor ( $h C C K B)$, or the cystic fibrosis transmembrane conductance regulator (hCFTR) (latter not shown), as described in Methods. Left lanes, size markers. Arrows indicate size of hCCK-A (300 bp), and hCCK-B (300 bp) predicted

from their defined sequences. $(B)$ Localization of CCK-A receptors to ductal cells in pancreatic adenocarcinoma by in situ hybridization. DIGlabeled oligonucleotide probes specific for CCK-A and CCK-B were incubated with sections obtained from normal pancreas or pancreatic adenocarcinoma. (B1) Micrograph of pancreatic adenocarcinoma sections hybridized with CCK-A receptor-specific antisense primer. (B2) Adjacent sections hybridized with CCK-A receptor-specific sense primer. $(C)$ Southern blot analysis of the CCK-A receptor gene in normal human pancreas and pancreatic adenocarcinoma. Genomic DNA was extracted from specimens of normal pancreas and pancreatic adenocarcinoma and subjected to Southern blot analysis using a CCK-A receptor-specific DIG-labeled oligonucleotide probe as described in Methods. Left lanes, size markers. Arrows indicate size of hCCK-A gene fragments.

these receptors are overexpressed (19). Furthermore, in some nonhuman pancreatic cancer models, expression of CCK-B receptors has been identified on malignant tissue but not on normal pancreas (19). The relationship between different animal models of pancreatic cancer and humans remains controversial $(21,43)$. The majority of human pancreatic adenocarcinomas appear to be of ductal cell origin, while pancreatic malignancy in most animal models arises in acinar cells. While it is possible that among different species there is significant variation in the cell of origin for pancreatic adenocarcinoma, there is also substantial evidence to support the possibility of a pancreatic stem cell capable of differentiation into ductal or acinar cell types (44). Further, transdifferentiation from acinar to ductal cell phenotype has been described as a potential link between exocrine pancreatic cell types $(21,45)$. Thus, pancreatic tumor development in animals and humans could originate in the same cell type, with variable subsequent differentiation.

The role of CCK-A or -B receptors in human pancreatic carcinogenesis remains unclear. The growth of several human neoplastic cell lines derived from pancreas (15), colon (46), and lung (47) is stimulated by CCK or gastrin in vitro. Functional CCK-B receptors have been demonstrated on human biopsy specimens of small cell lung (47) and colon cancers (46), implicating a potential role for CCK or gastrin in human carcino- genesis (48). The demonstration of novel CCK-A receptor expression specifically on ductal cells in pancreatic adenocarcinomas is intriguing. This unique expression could reflect the presumed ductal origin of human pancreatic tumors. CCK-A receptors may be expressed at very low levels in ductal cells in normal human pancreas, below the level of detection by current techniques (32). Tumorigenesis may expand the population of ductal cells, increasing the expression of CCK-A receptors. In addition, CCK-A receptors on ductal cells may play a direct role in mediating the process of pancreatic tumorigenesis.

Alternatively, these studies are consistent with the hypothesis that CCK-A receptors may be a feature only of the developing human pancreas. CCK-A receptors might predominate during human fetal pancreatic development, but their expression would be unnecessary in normal adult pancreas. It has been suggested that CCK mediates normal pancreatic growth and development (10). Previous studies in the calf have demonstrated the expression of CCK-A receptors during fetal development, but with a predominance of CCK-B receptors in the normal adult bovine pancreas (49). Expression of novel antigens by pancreatic neoplastic cells, including fetal markers, has been described (50). Accordingly, expression of CCK-A receptors in pancreatic adenocarcinomas may reflect the reexpression of fetal markers during tumorigenesis. The expression 
of CCK-A receptors by human fetal pancreas is currently under examination in this laboratory.

Pancreatic adenocarcinoma represents the fifth leading cause of cancer death in the United States (1). Although there is some evidence that early diagnosis and resection can result in improved long-term survival (51), there is a paucity of specific molecular markers to detect pancreatic adenocarcinoma or to identify patients at higher risk for cancer development $(39,40)$. Further study of the differential expression of CCK receptors may reveal CCK-A receptors as a useful biomarker for pancreatic adenocarcinoma diagnosis and management.

\section{Acknowledgments}

This research was supported by the W.W. Smith Charitable Trust, the Elsa U. Pardee Foundation, the American Cancer Society, and Targeted Diagnostics and Therapeutics, Inc. D.S. Weinberg is the recipient of National Institutes of Health grant CA71080.

\section{References}

1. Boring, C.C., T.S. Squires, T. Tong, and S. Montgomery. 1994. Cancer statistics, 1994. CA-Cancer J. Clin. 44:7-26.

2. Durbec, J.P., G. Chevilotte, and J.M. Bidort. 1983. Diet, alcohol, tobacco and the risk of cancer of the pancreas: a case control study. Br. J. Cancer. 47: 463-467.

3. Gold, E.B., L. Gordis, and M.D. Diener. 1985. Diet and other risk factors for cancer of the pancreas. Cancer. 55:460-467.

4. Zheng, W., J.K. McLaughlin, and G. Gridley. 1993. A cohort study of smoking, alcohol consumption and dietary factors for pancreatic cancer. Cancer Causes Control. 4:477-482.

5. Olsen, G.W., J.S. Mandel, R.W. Gibson, and L.W. Wattenberg. 1989. A case control study of pancreatic cancer and cigarettes, alcohol, coffee and diet. Am. J. Public Health. 79:1016-1019.

6. Lowenfels, A.B., P. Maissoneuve, G. Cavallini, and R.W. Ammann. 1993. Pancreatitis and the risk of pancreatic cancer. N. Engl. J. Med. 328:1433-1437.

7. Gullo, L., R. Pezzilli, and A.M. Morelli-Labate. 1994. Diabetes and the risk of pancreatic cancer. N. Engl. J. Med. 331:81-85.

8. Fontham, E.T., and P. Correa. 1989. Epidemiology of pancreatic cancer. Surg. Clin. North Am. 69:551-567.

9. Herrington, M.K., and T.E. Adrian. 1995. On the role of cholecystokinin in pancreatic cancer. Int. J. Pancreatol. 17:121-138.

10. Povoski, S.P., W. Zhou, D.S. Longnecker, R.T. Jensen, S.A. Mantey, and R.H. Bell. 1994. Stimulation of in vivo pancreatic growth in the rat is mediated specifically by way of cholecystokinin A receptors. Gastroenterology. 107: $1135-1146$.

11. Mainz, D.L., O. Black, and P.D. Webster. 1973. Hormonal control of pancreatic growth. J. Clin. Invest. 52:2300-2304.

12. Folsch, U.R., K. Winckler, and K.G. Wormsley. 1978. Influence of repeated administration of cholecystokinin and secretin on the pancreas of the rat. Scand. J. Gastroenterol. 13:663-671.

13. Howatson, A.G., and D.C. Carter. 1985. Pancreatic carcinogenesis enhancement by cholecystokinin in the hamster nitrosamine model. Br. J. Cancer. 51:107-114.

14. Douglas, B.R., R.A. Wouterson, J.B. Jansen, and A.J. DeJong. 1989. Influence of cholecystokinin and bombesin on azaserine induced lesions in the rat pancreas. Gastroenterology. 96:462-469.

15. Smith, J.P., S.T. Framer, and T.E. Solomon. 1991. CCK stimulates the growth of six human pancreatic cancer cell lines in serum free medium. Regul. Pep. 32:341-349.

16. Hudd, C., M.C. LaRegina, and J.E. Devine. 1989. Response to exogenous cholecystokinin of six human gastrointestinal cancers xenografted in nude mice. Am. J. Surg. 157:386-394.

17. Wank, S.A., J.R. Pisegna, and A. deWeerth. 1994. Cholecystokinin receptor family. Molecular cloning, structure, and functional expression in rat, guinea pig and human. Ann. NY Acad. Sci. 713:49-66.

18. Wank, S.A. 1995. Cholecystokinin receptors. Am. J. Physiol. 269:G628G646.

19. Zhou, W., S. Povoski, and R.H. Bell. 1993. Overexpression of messenger RNA for the cholecystokinin-A receptor and novel expression of messenger RNA for gastrin (cholecystokinin-B) receptor in azaserine induced rat pancreatic carcinoma. Carcinogenesis (Oxf.). 14:2189-2192.

20. Smith, J.P., G. Liu, V. Soundararajan, P.J. McLaughlin, and I.S. Zagon. 1994. Identification and characterization of CCK-B/gastrin receptors in human pancreatic cancer cell lines. Am. J. Physiol. 266:R277-R283.
21. Hall, P.A., and N.R. Lemoine. 1993. Models of pancreatic cancer. Cancer Surv. 16:135-155.

22. Poston, G.J., J. Gillespie, and P.J. Guillou. 1991. Biology of pancreatic cancer. Gut. 32:800-812.

23. Chomczynski, P., and N. Sacchi. 1987. Single step method of RNA isolation by acid guanidinium thiocyanate phenol chloroform extraction. Anal. Biochem. 162:156-157.

24. Puissant, C., and L.M. Houdebine. 1990. An improvement of the single step method of RNA extraction by acid guanidinium thiocyanate phenol chloroform extraction. Biotechniques. 8:148-149.

25. Beverley, S.M. 1994. Enzymatic amplification of RNA by PCR. In Current Protocols in Molecular Biology. F.M. Ausubel, R. Brent, R.E. Kingston, D.D. Moore, J.G. Seidman, J.A. Mith, and K. Struhl, editors. John Wiley \& Sons Inc., New York. 15.4.1-15.4.6.

26. Kramer, M., and D.M. Coen. 1994. Enzymatic amplification of DNA by PCR: standard procedures and optimization. In Current Protocols in Molecular Biology. F.M. Ausubel, R. Brent, R.E. Kingston, D.D. Moore, J.G. Seidman, J.A. Mith, and K. Struhl, editors. John Wiley \& Sons Inc., New York. 15.1.115.1.8.

27. Walther, W., U. Stein, and C. Eder. 1994. RNA analysis using miniprep RNA in reverse transcription PCR. Biotechniques. 17:674-675.

28. Bellacosa, A., D. deFeo, A.K. Godwin, D.W. Bell, I.Q. Cheng, D.A. Altomare, and M. Wan. 1995. Molecular alterations in the AKT-2 oncogene in ovarian and breast carcinomas. Cancer. 64:280-285.

29. Larsson, L.I., T. Christensen, and H. Dalboge. 1988. Detection of propiomelanocortin mRNA by in situ hybridization using a biotinylated oligonucleotide probe and avidin-alkaline phosphatase histochemistry. Histochemistry. 89:109-116.

30. Marchetti, D., I.E. McCutcheon, M.J. Ross, and G.L. Nicholson. 1995. Inverse expression of neurotrophins and neurotrophin receptors at the invasion front of human melanoma brain metastases. Int. J. Oncol. 7:87-94.

31. Wank, S.A., J.R. Pisegna, and A. de Weerth. 1992. Brain and gastrointestinal cholecystokinin receptor family: structure and functional expression. Proc. Natl. Acad. Sci. USA. 89:8691-8695.

32. Monstein, H.J., A.G. Nylander, A. Salehi, D. Chen, I. Lundquist, and R. Hakanson. 1996. Cholecystokinin-A and cholecystokinin-B/gastrin receptor mRNA expression in the gastrointestinal tract and pancreas of the rat and man. Scand. J. Gastroenterol. 31:383-390.

33. Trapnell, B.C., C.S. Chu, P.K. Paako, T.C. Banks, K. Yoshimura, V.J. Ferrans, M.S. Cherncik, and R.G. Crystal. 1991. Expression of the cystic fibrosis transmembrane conductance regulator gene in the respiratory tract of normal individuals and individuals with cystic fibrosis. Proc. Natl. Acad. Sci. USA. 88: 6565-6569.

34. Crawford, I., P.C. Maloney, P.L. Zeitlin, W.B. Guggino, S.C. Hyde, H. Turley, K.C. Gatter, A. Harris, and C.F. Higgins. 1991. Immunocytochemical localization of the cystic fibrosis gene product CFTR. Proc. Natl. Acad. Sci. USA. 88:9262-9266.

35. de Weerth, A., J. Pisegna, K. Huppi, and S.A. Wank. 1993. Molecular cloning, functional expression and chromosomal localization of the human cholecystokinin type A receptor. Biochem. Biophys. Res. Commun. 194:811818.

36. Doss, D.N., N.A. Mekhail, and E.Y. Ekladdios. 1991. The localization of cholecystokinin immunoreactivity in the rat ovary and uterine tube. Neuropeptides. 18:87-91.

37. Sacerdote, P., C.J. Wiedermann, L.M. Wahl, C.B. Pert, and M.R. Ruff. 1991. Visualization of cholecystokinin receptors on a subset of human monocytes and in rat spleen. Peptides (Tarryt.). 12:167-176.

38. Brennan, M.F., T.J. Kinsella, and E.S. Casper. 1993. Cancer of the pancreas. In Cancer-Principles and Practice of Oncology. vol. 1. V.T. Devita, S. Hellman, and S.A. Rosenberg, editors. J.B. Lipincott Company, Philadelphia. 849 .

39. Watanabe, H., N. Sawabu, Y. Songur, Y. Yamaguchi, O. Satomura, H Ohta, Y. Motoo, T. Okai, and T. Wakabayashi. 1996. Detection of k-ras point mutations at codon 12 in pure pancreatic juice for the diagnosis of pancreatic cancer by PCR-RFLP analysis. Pancreas. 12:18-24.

40. van Es, J.M., M.M. Polak, F.M. van den Berg, T.B. Ramsoekh, M.E. Craanen, R.H. Hruban, and G.J. Offerhaus. 1995. Molecular markers for diagnostic cytology of neoplasms in the head region of the pancreas: mutation of k-ras and overexpression of the p53 protein product. J. Clin. Pathol. (Lond.). 48:218-222.

41. Susini, C., A. Estival, and J.L. Scemama. 1986. Studies on human pancreatic acini: actions of secretagogues on amylase release and cellular cyclic AMP accumulation. Pancreas. 1:124-129.

42. Povoski, S.P., W. Zhou, D.S. Longnecker, and R. Bell. 1994. Cholecystokinin receptor characterization and cholecystokinin-A receptor mRNA expression in transgenic mouse pancreatic carcinomas and dysplastic pancreas. Oncol. Res. 6:411-417.

43. Logsdon, C.D. 1995. Pancreatic cut cell cultures: there is more to ducts than salty water. Gastroenterology. 109:1005-1009.

44. Iovanna, J.L., P.L. de la Porte, and J.-C. Dagorn. 1992. Expression of genes associated with dedifferentiation and cell proliferation during pancreatic regeneration following acute pancreatitis. Pancreas. 7:712-718. 
45. Hall, P.A., and N.R. Lemoine. 1992. Rapid acinar to ductal transdifferentiation in cultured human exocrine pancreas. J. Pathol. 166:97-103.

46. Hoosein, N.M., P.A. Keiner, R.C. Curry, and M.G. Bratttain. 1990. Evidence for autocrine growth stimulation of cultured colon tumor cells by a gastrin/cholecystokinin-like peptide. Exp. Cell Res. 186:15-21.

47. Matsumori, Y., N. Katakami, M. Ito, T. Taniguchi, N. Iwata, and T. Takaishi. 1995. Cholecystokinin-B/gastrin receptor: a novel molecular probe for human small cell lung cancer. Cancer Res. 55:276-279.

48. Rehfeld, J.F., and W.W. van Solinge. 1994. The tumor biology of gastrin and cholecystokinin. Adv. Cancer Res. 63:295-347.
49. Le Meuth, V., V. Philouze-Rome, I. Le Huerou-Luron, M. Formal, N. Vaysse, C. Gespach, P. Guilloteau, and D. Fourmy. 1993. Differential expression of the A- and B-subtypes of the cholecystokinin/gastrin receptors in the developing calf pancreas. Endocrinology. 133:1182-1191.

50. Escribano, M.J., J. Cordier, M. Nap, F. Ten Kate, and P. Burtin. 1986 Differentiation antigens in fetal human pancreas. Re-expression in cancer. Int J. Cancer. 38:155-160.

51. Trede, M., G. Schwall, and H.D. Saeger. 1990. Survival after pancreaticoduodenectomy. Ann. Surg. 21:447-458. 